\title{
PLANETARY DEFENCES
}

\section{Credit where credit is due.}

\section{BY S. R. ALGERNON}

"W e've lost another mining platform," said Overseer Kleeg. "A shaped antimatter charge breached the deflector field. Earther slaves don't have that sort of technology. I want you to find out if one of the major powers is conspiring against us."

Security Chief Vig'lah clicked his front pincers in frustration. "I would have detected any plot, Overseer. We should not overlook the possibility that the Earthers acquired the weapon themselves. You've seen their video transmissions. For a race incapable of interstellar travel, they are particularly sophisticated in their countermeasures against invasion."

"But those transmissions were fiction."

"Nevertheless, Overseer, we have taken precautions. We set up quarantine zones against microbes. We kept our weapons and written materials under lock and key including all cookbooks. We sealed off the mother ship and confiscated all laptop computers. Earthers must have other tricks that we did not anticipate. You have my word, Overseer. I will uncover them."

"Success at last," said Vig'lah. He stridulated with joy.

"We have lost two more platforms," said Kleeg. "Get to the point."

"Some of our subcontractors use antimatter power for their tractor beams. I noticed that requisitions for replacement parts have increased lately at several construction sites. The Earthers could have used parts from these sites to build a bomb."

"Earthers have broken into our construction sites?” Kleeg's antennae retracted.

"No, no," said Vig'lah. "The security perimeter was not at fault. We found a note to one of the construction managers in the debris of one of the platforms. It says: 'Little Annie is only seven years old, and she will die of - this word is untranslated, but it must be some local malady — unless we can supply power to the abandoned hospital near crater 437. Please accept 2,000 galactic credits in exchange for one magnetic bottle of antimatter. If you help us save dear Annie's life, we will be overjoyed. Production will surely increase by $15 \%$ next cycle"."

"They are a conquered people," said Kleeg. "How did they get access to galactic currency? Who would have paid them?"

"You have my word, Overse - "

"Enough promises. Get to work."

“Overseer, I have news," said Vig'lah. He spoke solemnly. Three platforms had fallen since his last audience with Kleeg, so he could not gloat. He carried a display tablet in his forward pincers.

"Very well. Speak."

"After scanning the planet for the RF signature of galactic currency, we found 20,000 credits in an impact crater on a remote coastline. Officially, the impact was from an obsolete surveillance satellite, but I believe that the money had been hidden inside the satellite prior to its descent."

"Only the Communications Guild has access to orbital satellites. Could they really have turned against us?"

"They would be a formidable enemy," said Vig'lah. "However, I have made discreet enquiries. It turns out that a delegation from the Communications Guild visited the planet one cycle ago. Their visit coincided with an entertainment broadcast by the natives. We did not think much of it at the time."

"Native broadcasts? Isn't that dangerous?"

"It boosted morale. We had our censors vet every transmission. Earther entertainment can be quite outlandish, and we thought - "

"Is that the transcript you've got there?"

"Well, yes, but please understand -"

Kleeg snatched up the transcript. He read with a growing sense of foreboding.

Greetings. I am being called the Esteemed Denzel Gatez Starbuck, last in line to be Prince of Planet Earth. In times past, my family amassed large fortune in the Earth Province of West Prometheus, valued at 1.3 MILLION galactic credits. Unfortunately, during Invasion of my Planet, the monies were buried by an atomic blast. If you could provide us with 20,000 galactic credits for the equipment to recover the vault, we would gladly remit to you $50 \%$ of the riches within. Have a joyous cycle.

Kleeg could not bear to read any further.

"Tell me," he said, "that you can put an end to these transmissions."

"Alas, the natives have used their proceeds to buy access to the interstellar net from the Communications Guild. Fortunately, their encryption is primitive, so we can tell what they are up to. Some of their messages depict members of the starfaring civilizations in scandalous states of undress. Some of them offer to sell land - on Jupiter, of all places. Inbound financial transactions have increased by three orders of magnitude.

These are heavily encrypted, but I suspect a substantial influx of credits to Earth. The loyalty of the independent contractors can no longer be assured."

"You are Security Chief. Surely you can find some pretext for shutting down planetary communications."

"I'm afraid not. The recent loss of mining platforms has substantially reduced the value of your collateral. My sources say that the mining venture will soon be bankrupt, and that a consortium of natives is set to buy the remaining platforms."

"I have heard nothing from High Command. How do you know this?"

"Apparently, the natives are in need of a security chief. They value my knowledge of the local mining operations, and they appreciate it that I allowed them to broadcast their movies back when they worked for you. I am here to offer my resignation."

Kleeg relaxed his internal air bladders. I should have known, he thought, that the Earthers would not make things easy.

"What will you do?" asked Vig'lah. "The natives probably have no use for an overseer."

Maybe not, thought Kleeg, but there's still time to reassemble the invasion fleet. After Vig'lah had left, Kleeg tracked down one of the captured laptops. Somewhere in its memory, Kleeg knew, there was an Earther trick that would save the expedition from ruin.

Only 18 standard galactic cycles to go! Pledge 100 credits and win an "I HELPED CONQUER THE EARTH” T-Shirt!

The Earthers can keep Vig'lah - and their fake princes, too, thought Kleeg. I don't need them, not when I've got QuickConquer.

S. R. Algernon studied fiction writing and biology, among other things, at the University of North Carolina at Chapel Hill. He currently lives in Singapore. 